\title{
Correlation of ECG Changes With Coronary Angiographic Morphology in Patients Presented With Rest Pain
}

\author{
S SHARMIN $^{1}$, MA SIDDIQUE ${ }^{2}$, MK AHMED ${ }^{3}$, KMHS S HAQUE ${ }^{4}$
}

\begin{abstract}
The study was performed to see the correlation of ECG changes with CAG findings in patients of unstable angina presented with prolonged rest pain. A total 30 cases were taken and was divided into three groups according to their ST segment and T wave changes in ECG. Echocardiogram was done and selective coronary angiogram was performed in all patients within 5 to 15 days of presentation. The study showed that patient with significant ECG change had more extensive coronary artery involvement than the patients with less significant ECG change or normal ECG with better preserved ejection fraction. So ECG changes can give a clue about severity, long-term prognosis and outcome of the disease.
\end{abstract}

(University Heart Journal 2007; 3 : 57-59)

\section{Introduction}

Prolonged rest pain is one of the three important clinical presentations of unstable angina. Rest angina can be defined as angina that occurs at rest or minimal exertion usually lasting more than 20 minutes $^{1}$. Although unstable angina represents a clinical condition presenting very similarly to non-ST segment elevation myocardial infarction but there is no evidence of myonecrosis by some form of elevation of cardiac markers. Patients with prolonged rest pain are considered to be included in highrisk groups ${ }^{2}$. Patients with rest angina commonly presented with transient ST-T changes in ECG. A common ECG pattern in patients with unstable angina is a persistent negative $\mathrm{T}$ wave over the involved area. Deeply negative $\mathrm{T}$ wave across all the precordial leads suggest a proximal severe left anterior descending coronary artery stenosis as the culprit lesion. The present study provides a systematic prospective correlation of different ECG changes in patients presenting with rest angina with angiographic profile and tried to find out the prediction of severity of coronary artery involvement from ECG changes.

1. Dr. Shahnur Sharmin, Lecturer, Dhaka Medical College, Dhaka

2. Prof.. Md. Abu Siddique, Professor of Cardiology, UCC, BSMMU, Dhaka

3. Dr. Md. Khurshed Ahmed, Assistant Professor of Cardiology, UCC, BSMMU, Dhaka

4. Prof. KMHS Sirajul Haque, Professor of Cardiology, UCC, BSMMU, Dhaka

Address of Correspondence: Dr. Shahnur Sharmin, Lecturer, Dhaka Medical College, Dhakja
Material and Methods

A prospective randomized study was carried out during the period of January 2005 to July 2006. The study was done in Department of Cardiology, BSMMU. A total 30 patients presented with prolonged rest pain was included in the study. Patients with post infarction angina, with elevated serum marker and previously abnormal ECG like LBBB, LVH with strain pattern, post PTCA or CABG patients were excluded from the study. After inclusion, the patients were properly interviewed, meticulous history taking and physical examination were performed. A resting ECG was done. Other relevant investigations including an echocardiogram were also done. His ECG was interpreted carefully. Selective coronary angiogram was performed within 5 to 15 days of presentation. Qualitative and quantitive morphologic analysis was performed. The patients were divided into 3 groups according to ECG presentation. Group I comprised ST segment elevation or depression of at least $1 \mathrm{~mm}$ and /or marked $\mathrm{T}$ wave inversion. Group II comprised patients with ST segment depression less than $1 \mathrm{~mm}$ or $\mathrm{T}$ wave inversion and patients with normal ECG were included in group III.

\section{Results}

The age of the subjects were ranging from 30 to 80 years. The mean age was $53.3++_{-} 4.1$ years. Male sex was predominant. In group I, $80 \%$ patients were male. In group II and III male patients were $90 \%$ and $77 \%$ respectively. Among the 30 patients 7 patients were included in group 1.10 patients in group II and 13 patients in group III. Echocardiography was done and study of ejection fraction revealed that patients with significant ECG change consisted in group I showed $71 \%$ patients with EF $>50 \%$ and $14 \%$ patients with $\mathrm{EF}<40 \%$. In group II with less significant ECG change, most of the patients (90\%) presented with normal EF and group III with normal ECG change showed the similar result. Coronary angiogram was done and revealed that triple vessel disease was predominant in group I $(57 \%)$. On the other hand, it was only $30 \%$ in group II and $15 \%$ in group Ill. Subjects presented with less marked ECG changes or normal ECG has got less extensive coronary artery lesion. When lesion morphology was compared between the groups, group I with marked ECG changes showed type C lesion in 57\% cases. On the other hand, group II and group III presented 
with type A and type B lesion predominantly. A 23\% subject with normal ECG has got normal coronary arteries. Regarding TIMI flow studies among the study population, grade III TIMI flow was predominant in group III and group 11 (38.5\% and $30 \%$ respectively), whereas grade I TIMI flow was commonly seen in group I (43\%).

Table 1

Distribution of the subjects by sex $(n=30)$

\begin{tabular}{lccc}
\hline Sex & $\begin{array}{c}\text { Group I } \\
\mathrm{n}=7\end{array}$ & $\begin{array}{c}\text { Group II } \\
\mathrm{n}=10\end{array}$ & $\begin{array}{c}\text { Group III } \\
\mathrm{n}=13\end{array}$ \\
& no. $(\%)$ & no. $(\%)$ & no. $(\%)$ \\
\hline Male & $6(85.7)$ & $9(90)$ & $10(77)$ \\
Female & $1(14.3)$ & $1(10)$ & $3(23)$ \\
\hline
\end{tabular}

Table-II

Distribution of subjects by echo finding - ejection fraction $(E F)(n=30)$

\begin{tabular}{lccc}
\hline EF $(\%)$ & $\begin{array}{c}\text { Group I } \\
\mathrm{n}=7 \\
\text { no. }(\%)\end{array}$ & $\begin{array}{c}\text { Group II } \\
\mathrm{n}=10 \\
\text { no. }(\%)\end{array}$ & $\begin{array}{c}\text { Group III } \\
\mathrm{n}=13 \\
\text { no. }(\%)\end{array}$ \\
\hline$<30$ & 0 & 0 & 0 \\
$30-39$ & $1(14.3)$ & $0(0)$ & $0(0)$ \\
$40-49$ & $1(14.3)$ & $1(10)$ & $2(15.4)$ \\
$>=50$ & $5(71.4)$ & $9(90)$ & $11(84.6)$ \\
\hline
\end{tabular}

Table-III

Distribution of the subjects by extent of disease $(n=30)$

\begin{tabular}{lccc}
\hline Extent ofdisease & $\begin{array}{c}\text { Group I } \\
\mathrm{n}=7 \\
\text { no. }(\%)\end{array}$ & $\begin{array}{c}\text { Group II } \\
\mathrm{n}=10 \\
\text { no. }(\%)\end{array}$ & $\begin{array}{c}\text { Group III } \\
\mathrm{n}=13 \\
\mathrm{no.}(\%)\end{array}$ \\
\hline SVD & $1(14.3)$ & $3(30)$ & $6(46.2)$ \\
DVD & $2(28.6)$ & $3(30)$ & $2(15.4)$ \\
TVD & $4(57.2)$ & $3(30)$ & $2(15.4)$ \\
Normal & $0(0)$ & $1(10)$ & $3(23.1)$ \\
\hline
\end{tabular}

\section{Table-IV}

Distribution of the subjects by lesion morphology $(n=30)$

\begin{tabular}{lccc}
\hline Lesionmorphology & $\begin{array}{c}\text { Group I } \\
\mathrm{n}=7 \\
\mathrm{no} .\end{array}$ & $\begin{array}{c}\text { Group II } \\
\mathrm{n}=10 \\
\mathrm{no.}(\%)\end{array}$ & $\begin{array}{c}\text { Group III } \\
\mathrm{n}=13 \\
\mathrm{no.}(\%)\end{array}$ \\
\hline Type A & $2(28.6)$ & $4(40)$ & $5(38.5)$ \\
Type B & $1(14.3)$ & $3(30)$ & $2(15.4)$ \\
Type C & $4(57.2)$ & $2(20)$ & $1(7.7)$ \\
Normal & $0(0)$ & $1(10)$ & $3(23.1)$ \\
\hline
\end{tabular}

Table-V

Distribution of the subjects by TIMI Flow grade $(n=30)$

\begin{tabular}{|c|c|c|c|}
\hline Grade & $\begin{array}{c}\text { Group I } \\
\mathrm{n}=7 \\
\text { no. }(\%)\end{array}$ & $\begin{array}{c}\text { Group II } \\
n=10 \\
\text { no. }(\%)\end{array}$ & $\begin{array}{c}\text { Group III } \\
\mathrm{n}=13 \\
\text { no. }(\%)\end{array}$ \\
\hline G0 & $1(14.3)$ & $0(0)$ & $1(7.7)$ \\
\hline GI & $3(42.9)$ & $3(30)$ & $1(7.7)$ \\
\hline GIl & $1(14.3)$ & $4(40)$ & $4(30.8)$ \\
\hline GIll & $2(28.6$ & $3(30)$ & $5(38.5)$ \\
\hline
\end{tabular}

\section{Discussion}

A total of 30 patients with prolonged or rest chest pain were grouped into three groups according to their ECG (ST segment and $\mathrm{T}^{\mathrm{I}}$ wave) changes. All patients undergo echocardiographic evaluation and coronary angiogram. The mean age group of the study subjects was 53.3 years indicating the higher prevalence of unstable angina after the age $f 50$ yrs. Male patients were predominant in all the three study groups showing the similarity with the study done by Dangus et al (1997), Haque et al (2004) and Siddique et al $(2005)^{3,4,5}$. EF was better preserved in groups presented with normal ECG or less marked ECG changes. $90 \%$ patients with less marked ECG changes has got EF $>50 \%$ and $85 \%$ with normal ECG has got EF $>50 \%$. Whereas patients with significant ECG changes showed EF $<40 \%$ in $29 \%$ patients. So. It was found that left ventricular systolic function was better preserved in patients with unstable angina presented with less significant ECG changes or normal ECG. Coronary angiogram was done in all patients and extent of involvement and type of lesion was noted. TIMI flow grade was also observed. It was found that patients with significant ECG changes showed more extensive coronary artery involvement and predominant type $\mathrm{C}$ lesion. Whereas patients with normal ECG showed normal coronary arteries in $23 \%$ subjects. Patients with less significant ECG changes also showed less extensive coronary artery involvement. This finding is consistent with de Servi et al (1985) who showed a larger number of patients with unstable angina showing ST segment change had multi-vessel disease and lower values of LV systolic function ${ }^{\mathrm{s}}$.

\section{Conclusion}

The degree of ST segment and T wave changes in patients with rest angina can allow a classification of patients included into the broad spectrum of unstable angina. This distinction should be taken into consideration in studies aimed at evaluating long-term prognosis or the results of medical or surgical therapies. 


\section{References}

1. Betriu A, Heras M, Cohen M, Fuster V,.'Unstable Angina: Outcome according to clinical presentation', J Am Coll Cardiol,1992; 19: 1659-1663.

2. Braunwald E. 'Unstable Angina: An etiologic approach to management (editorial), Circulation 1998; 98: 2219-2223.

3. Dangus G, Roxana M, Wallensten S, Nikolaos A, Kakarala, V Ambrose A. Correlation of Angiographic Morphology and Clinical Presentation in Unstable Angina, J Am Coll Cardiol 1997; 29: 519-25.
4. Haque F. Severity of Unstable Angina and C reactive protein - Clinical, Biochemical and Angiographic Study, MD thesis, 2004 Bangabandhu Sheikh Mujib Medical University, Dhaka, Bangladesh.

5. Siddique M.A. Cardiovascular Risk Factors Profile of Unstable Angina Patients in Bangladesh', University Heart Journal 2005;.1: 10-12.

6. De Servi, S Arbustini, E Marsico, F Bramucci, E Angoli, L Porcu, E Valentine P. 'Correlation Between Clinical and Morphologocal Findings in Unstable Angina', Am J Cardiol1995; 77:128-32. 